\title{
Socio-Economic Characteristics of Microfinance Beneficiaries in Ghana - Evidence from Sinapi Aba Trust Microfinance Institution
}

\author{
Ernestina Fredua Antoh \\ Ernestina Fredua Antoh (PhD) Senior Fellow \\ Bureau of Integrated Rural Development (BIRD) \\ Kwame Nkrumah University of Science \& Technology (KNUST) \\ PMB UPO Kumasi, Ghana.
}

Francis Enu-Kwesi

Francis Enu-Kwesi (PhD) Senior Fellow

Institute for Development Studies (IDS), University of Cape Coast (UCC).

\author{
Monica Addison \\ Monica Addison (MSc) Assistant Research Fellow \\ Bureau of Integrated Rural Development (BIRD) \\ Kwame Nkrumah University of Science and Technology (KNUST) \\ PMB UPO Kumasi, Ghana.
}

\begin{abstract}
The paper offers empirical authenticationof the assumption that microfinance beneficiaries are generally characterized by certain socio-economic attributes with evidence from the Sinapi Aba Trust (SAT) microfinance beneficiaries. Data were gathered from 361 randomly sampled beneficiaries using a mixed method design and cross-sectional survey approach, with a focus on the social and economic profiles of respondents. Descriptive analysis was used to present the socio-demographic and economic characteristics.The results support the common assumption that microfinance beneficiaries comprise mainly low income women engaged in informal activities. Largely, the beneficiaries were economically active, with basic level education, mostly married, and a bigger percentage had been on SAT program for up to five years. Their businesses were predominated by retail trade, small-scale manufacturing, services, food and agriculture, all of which generally required smaller start-up capital, and their sources of start-up funds were mainly from individual or family savings. The paper recommends the documentation of baseline characteristics of beneficiaries by microfinance institutions to facilitate trend and transformation analysis.
\end{abstract}

Keywords: Microfinance, socio-economic, characteristics, beneficiaries, Sinapi Aba Trust

\section{INTRODUCTION}

Microfinance institutions provide financial intermediation to the poor with the ultimate aim of creating employment and income opportunities to improve the socio-economic conditions of beneficiaries. Microfinance beneficiaries collect loans, in the form of individual and group loans, to undertake business activities. These businesses raise income and consumption levels of families, reduce income inequality and enhance socio-economic welfare (Mahjabeen, 2008) 
[32].According to Rankin (2002) [36] and Nader (2008) [34], beneficiaries comprise mainly poor households with low educational levels, inconsistent incomes and unstable living environments, and these characteristics are limitations that adversely affect the majority of them. Duryea and Pages (2002) [14] and Shane (2003) [41] for instance, have indicated that exploitation of entrepreneurial opportunity depends to a large extent on factors such as the entrepreneur's level of education, skills or knowledge acquired through work experience, social network and credit. They added that generally, microfinance helps to offset the exclusion of people with poor socio-economic characteristics from the formal banking sector.

The microfinance sector in Ghana has grown and developed to its present state through various financial sector policies and programmes undertaken by different governments. Among these are the provision of subsidized credits in the 1950s, the establishment of the Agricultural Development Bank in 1965 which concentrated on the financial needs of the fisheries and agricultural sector. The establishment of Rural and Community Banks (RCBs) then followed with the introduction of a regulation that commercial banks should set aside 20 percent of their total portfolio for the promotion of lending to agriculture and small-scale industries in the 1970s and early 1980s (Asiamah \& Osei, 2007) [6]. Alongside the government's efforts, various non-formal financial institutions including Sinapi Aba Trust (SAT) evolved to provide financial services for productive small and medium-scale businesses with substantial investments. These institutions claim that their services were mainly sourced by low income business operators who are likely to fall within a particular socio economic status.

Despite the emphasis on socio-economic characteristics in the overall development of low income people, few studies on microfinance had focused on the socio-economic characteristics of beneficiaries in order to provide sufficient evidence on the socio-economic nature of people that microfinance beneficiaries reach out to and aim to transform. This study thus, explores the socio economic characteristics of SAT microfinance beneficiaries in Ghana as a contribution to literature. SAT has a long standing establishment in the country with impressive growing client strength probably due to the social and economic capital development that SAT forges among members. SAT is currently one of the leading MFIs in the country and it continues to expand geographically and complements its portfolio with diverse services and features.It has operated since 1994 as a non-governmental financial organization in the Ashanti region and its activities have important economic and social consequences on the businesses of beneficiaries.

SAT's microfinance activities in the Ashanti Region cover seven districts. These are the Kumasi Metropolis, Offinso, Mampong, Obuasi and Asante Akyem municipalities and Ejura Sekyedumase and Atwima Nwabiagya districts. The Ashanti Region, with a population of $4,725,046$ is the most populous region in Ghana (GSS, 2011) [20], thus a study on the socio economic characteristics of microfinance beneficiaries in the region is of major relevance for microfinance studies in Ghana and other developing countries. The purpose of the study is to analyse the characteristics of the SAT microfinance beneficiaries to comprehend the socio economic position of the beneficiaries to facilitate relevant policies and programmes for the various socio economic categories and for future comparative studies on beneficiaries.

\section{LITERATURE REVIEW}

\section{Overview of microfinance}

Robinson (2001) [37] and Khavul (2010) [28] describe microfinance as an emerging phenomenon in the field of development, first coming into prominence in the 1970s. Before that, from the 1950s through to the 1970s, the provision of financial services, by donors or governments were mainly in the form of subsidized rural credit programmes which were not 
able to reach poor rural households. From Yunus' (2003) [43] point of view, providing easy and affordable access to financial services for poor families can affect incomes and businesses which correspond with the underlying philosophy of microfinance. Along similar lines, BorteiDoku and Aryeetey (1995) [9] found that microfinance activities have included individual savings collectors, rotating savings clubs and credit associations, savings and credit clubs, moneylenders, trade creditors and personal loans.

In Ghana, the sector experienced a shift from a restrictive financial regime to a liberalized regime in 1986 which culminated in the promulgation of PNDC Law 328 in 1991 to allow the establishment of different categories of non-bank financial institutions, including savings and loans companies, and credit unions. According to Asiamah and Osei (2007) [6], these policies led to the emergence of three categories of microfinance institutions in Ghana. These categories are formal suppliers, such as savings and loans companies, rural and community banks and development and commercial banks. The next category comprises semi-formal suppliers such as credit unions, financial non-governmental organizations (FNGOs), and cooperatives (Asiama \& Osei, 2007) [6].

\section{Background characteristics of microfinance beneficiaries}

Background characteristics are personal characteristics such as age, sex, and marital status, size of household and years of education and can influence the effects of programmes on beneficiaries. According to Armendáriz de Aghion and Morduch (2005) [7] and (Ghalib, 2009) [17], the earlier and prototype microfinance institutions such as the Grameen Bank made women the core beneficiaries of their programmes. Considering the sex and marital composition of respondents in a study of microfinance, which mostly comprise women (Cheston \& Kuhn, 2002) [12], is important for operational purpose and policy formulation. It facilitates comparative analysis and also ascertains whether microfinance programmes reach out to the target population.

Economists and social scientists have been theorizing about a causal relationship between financial development and socio-economic development (Afful \& Annim, 2008) [3] and studies have been undertaken to validate the relationships. It is presumed that financial intermediation could have both micro and macro level impacts. At the micro level it could produce social effects at the individual level, more especially, when most microfinance institutions, such as Sinapi Aba Trust (SAT), (2008) [42] complement their financial products with non-financial services such as awareness creation on topical issues, education loans for children and organizing social forums for beneficiaries to enhance socio-economic development.The macro level could produce structural changes in social networks which may be measured by the involvement of the poor, women and marginalized groups in social and economic activities. Zohir and Matin (2004) [44] note that financial institutions have wider effects on economic, social, cultural and political lives at the macro perspective. Owing to the enormous recognition of the poor socio-economic characteristics of beneficiaries on poverty reduction, microfinance becomes significant in facilitating the availability of information that leads to a trend analysis of socio-economic development.

It has been found that microfinance beneficiaries comprise mainly poor households with low educational levels, inconsistent incomes and unstable living environments (Nader, 2008 [34]; Rankin, 2002 [36]). Ikeanyibe (2008) [26] has recognized that background characteristics of people such as sex, household size and level of skills help to explain the initiative to set up and manage businesses and can also influence choices of development and decision making. Gibb (2008) [23] states that background characteristics could influence loan sizes, networks and 
capital accumulation. For instance low education is presumed to have negative effects on accessing and utilizing microcredit as well as credit information that are necessary for good business performance.Thus, irrespective of the notion that acquisition of financial capital could have positive effects on the lives of beneficiaries (Benhabib \& Spiegel, 1994) [8], it may not have the effects it deserves, depending on some individual characteristics.

Matin and Begum (2002) [33] note that when financial structures aimed at improving the lives of the poor fail to address such limitations they delay the process of getting the poor out of poverty. For instance low education is presumed to have negative effects on accessing and utilizing microcredit as well as credit information that are necessary for good businessperformance and could affect discovery of entrepreneurial opportunities (Ekpe, Mat \&Razak, 2010 [15]; Kotir \& Obeng-Odoom, 2009 [29]). Furthermore, the number of years that beneficiaries have benefited from loans could give information on the issue concerning cyclic borrowing by beneficiaries. Its effect on the accumulation of assets has become an important component in the impact of microfinance programmes. Hossain (1988) [25] has observed in a cross sectional study that compared beneficiaries who had been on the program for over three years and new ones and concluded that investment in fixed assets was about 2.5 times higher for the beneficiaries with more than three years than for those who joined during the year of the survey.

\section{Overview of the Study Area}

\section{METHODS}

The study was conducted in Adum in the Kumasi Metropolis, Obuasi Municipality and Ejura Sekyedumase district in the Ashanti Regionwhich is centrally located in the middle belt of Ghana. The study area has had well established links with SAT regarding its operations and there is much to be learned from the beneficiaries. The economy of the study area which is characterized by low income people is dominated by the services sector, which employs about 71 percent of the labor force with the industrial and agriculture sectors employing 24 percent and five percent respectively (KMA, 2005) [31]. In terms of commerce, it has the largest market centre in Ghana which is the Kumasi central market. Obuasi is where the famous and rich Obuasi Gold Mines, now Anglo Gold Ashanti is located. Agriculture and food constitute a major source of revenue for a large number of inhabitants. Commerce and small-scale industrial activities thrive in Obuasi and most of its surrounding communities. Many people are selfemployed and depend on several sources, such as self, relatives and microfinance finance institutions for financial services. Ejura Sekyedumase District is one of the districts with a high figure of 10 percent of self-employed with employees (GSS, 2005) [18] probably due to the existence of medium to large-scale commercial farmers who employ many farm hands. The District serves as the immediate link between the north and south and it has most migrants from the Northern regions.

\section{Population and Sampling Procedures}

The multi-stage sampling method was used. Out of SAT's seven branches in the Ashanti Region, three branches were purposively selected mainly due to their ability to provide diverse information relevant to the study. After selecting the branches the second stage utilized existing information from SAT to cluster the target population in each branch into loans types. The next stage of the sampling process used proportionate simple random sampling via Excel RAND procedure to select the required sample size from each branch based on SAT beneficiary list provided by staff. Key informants comprising loan officers, branch managers and the chief executive officer were purposively sampled for data collection.The target beneficiaries were those who had been on the scheme for a minimum of two years with at least four loan cycles. From the total population of 8734 beneficiaries, the table of sample size determination 
developed by Krejcie and Morgan (1970) 30] (as cited in Sarantakos, 2005) [38] was used to arrive at an initial sample size of 368 beneficiaries, premised on a confidence level of 95 percent and a margin of error of five percent, which is acceptable for social science research. Field challenges however, reduced the sample size to 361.The study used the cross-sectional design and a combination of quantitative, qualitative, and participatory methods of data collection and analysis. The quantitative method dealt mainly with economic indicators, while the qualitative and participatory methods examined social indicators. Main survey instruments used were interview schedules and focus group discussion guides.The descriptive approach was used for a systematic collection of in-depth information on socio-economic characteristics. Descriptive statistical tools such as, tables, frequencies and percentages were used to present the obtained information.

\section{RESULTS AND DISCUSSIONS}

The results are presented in two subsections. The first subsection addresses the socioeconomic characteristics of the respondents, while the second section focuses on the business characteristics.

\section{Socio-economic characteristics of SAT beneficiaries}

Beneficiaries' social and economic characteristics were identified as sex, marital status, age, number of children, highest amount of loan, type of loan and loan cycle.

\section{The Sex and Marital Composition of Beneficiaries}

The sex composition analysis revealed that 74.2 percent of the respondents were females with males comprising 25.8 percent. The result supports observation that microfinance operations assist mainly the poor and women engaged in informal activities (Ghalib, 2009 [17]; Khandker, 2005 [27]).Marital status can also influence the roles and responsibilities as well as occupational lives of members and their families (Dennis \&Peprah, 1995) [13]. It could also have an effect on family budget. From the total number (361) of respondents, 77.3 percent were married while the remaining 22.7 percent were single, divorced and widowed. The percentage $(90.6 \%)$ of those who had ever married was higher than the national percentage of 58.5 given by the Ghana Statistical Service (GSS) (2008) [19].

Table 1: Sex and marital status distribution of respondents

\begin{tabular}{llrrrrrrrrrrrrr}
\hline & \multicolumn{2}{c}{ Single } & \multicolumn{2}{c}{ Married } & \multicolumn{2}{c}{ Divorced } & \multicolumn{2}{c}{ Widowed } & \multicolumn{3}{c}{ Separated } & \multicolumn{2}{c}{ Total } \\
Sex & No. & $\%$ & \multicolumn{1}{c}{ No. } & $\%$ & \multicolumn{1}{c}{ No. } & $\%$ & \multicolumn{1}{c}{ No. } & $\%$ & No. & $\%$ & No. & \multicolumn{1}{c}{$\%$} \\
\hline Female & 22 & 6.1 & 208 & 57.6 & 15 & 4.2 & 22 & 6.1 & 1 & .3 & 268 & 74.2 \\
Male & 12 & 3.3 & 71 & 19.7 & 2 & .6 & 8 & 2.2 & 0 & .0 & 93 & 25.8 \\
\hline Total & 34 & 9.4 & 279 & 77.3 & 17 & 4.7 & 30 & 8.3 & 1 & .3 & 361 & 100.0 \\
\hline
\end{tabular}

Source: Field survey, 2012

The age distribution of respondents indicates that 30.7 percent and 40.2 percent of the respondents were in the age groups of $31-40$ and $41-50$ years respectively. Largely, the respondents comprised the economically active population with only 3.6 percent above 60 years as shown in Figure 1. This is consistent with the International Labor Organization's (ILO) standard for economically active age categorization which is from 15 up to 55 years and the Ghana Statistical Service's (2008) [19] standard of between 15 and 64 years. 


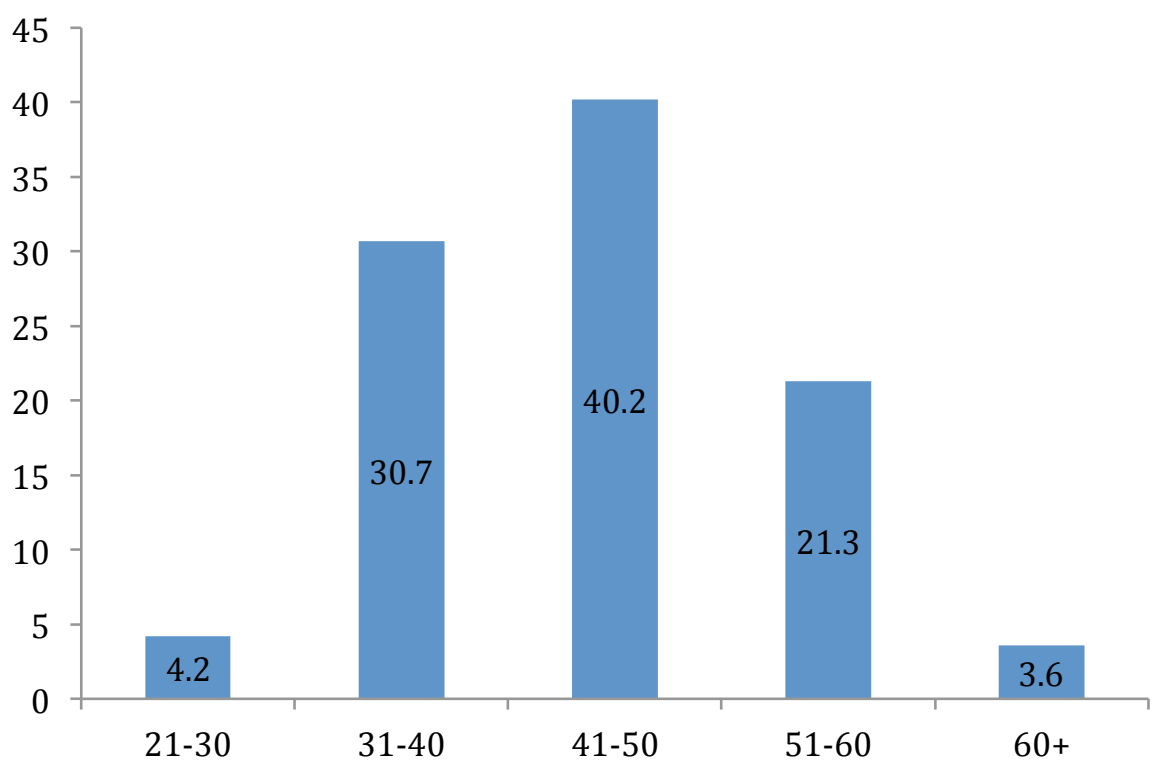

Figure 1: Age composition of beneficiaries Source: Field survey, 2012

The ages of the respondents varied from 21 years to 72 years with a mean age of 43 years. This could be attributed to the eligibility criteria and the application assessment requirements of SAT which among others demand previous business transactions and experiences of beneficiaries making it difficult for people below 20 years to qualify. Ekpe, Mat and Razak (2010) [15] have contended that individual characteristics such as age affect discovery of entrepreneurial opportunities. Thus, the results indicate that most of the beneficiaries were adults and could take decisions on their businesses and investment choices.

It also helps to understand and appreciate the responsibilities of beneficiaries towards the development of their family members. For instance, Hazarika and Sudipta (2007) [24] found out that larger families are more likely to withdraw their children from school to attend to their family needs. Beneficiaries who are mainly sole owners and managers are also likely to rely on family members, especially own children as auxiliary workers.

Table 2: Number of children of respondents

\begin{tabular}{ccc}
\hline Number & Frequency & Percent \\
\hline 0 & 14 & 3.9 \\
1 & 18 & 5.0 \\
2 & 54 & 15.0 \\
3 & 80 & 22.0 \\
4 & 85 & 23.5 \\
5 & 54 & 15.0 \\
$6+$ & 56 & 15.6
\end{tabular}

Source: Field survey, 2012 
The number of children per respondent varied from zero to ten. About 22.2 percent and 23.5 percent of respondents had three and four children respectively. Nearly, 30.6 percent had five or more children. The results correspond with the average age of 3.76 and a median of 4.00 which is typical of the average household size of four in Ghana (GSS, 2008) [19]. The overall statistics however, indicated a negative skewness of -259. This is an indication of an uneven distribution of number of children among respondents. According to Pallant (2005) [35], a normal distribution is represented by a skewness of 0.0 . It can therefore, be inferred that the number of children per respondents was not normally distributed.

Majority (51.4\%) of the respondents had basic education, followed by 15.5 percent who had no formal education and 15.2 percent who had secondary school education. The commercial and technical levels which have the potential of training middle level technical people had been attained by only 5.5 percent of respondents. The remaining had attained post-secondary education (10.2\%) and tertiary level education $(2.2 \%)$ respectively.Regarding the study respondents whose ages were from 21 years, 15.5 percent had no basic education and could not write simple statements with the remaining 84.5 percent being literate.

According to GSS (2012) [21], a person was considered literate if he or she could write a simple statement with understanding. About 71.5 percent of the Ghanaian population aged 15 years and above were literate with the remaining 28.5 being non-literate in 2010. Table 3 provides details of beneficiaries' educational levels.

Table 3: Educational attainment of respondents

\begin{tabular}{lcc}
\hline Educational level & Frequency & Percent \\
\hline No formal education & 56 & 15.5 \\
Basic & 185 & 51.4 \\
Secondary & 55 & 15.2 \\
Commercial/Technical/Vocational & 20 & 5.5 \\
Post-secondary & 37 & 10.2 \\
University & 8 & 2.2 \\
\hline Total & 361 & 100.0 \\
\hline
\end{tabular}

Source: Field survey, 2012

The results show that literacy rate of the beneficiaries was higher than the national average. However, generally the results show a decrease in the participation of the beneficiaries in post basic education which is common among poor and low income population.

\section{Business Characteristics of Respondents}

The business characteristics of respondents could have influence on their business incomes and other related features (Hossain, 1988) [25]. The business aspects considered in this section entail the number of years that respondents have been with SAT, sources of start-up capital, type of loans and sex composition, number of loan cycles received and types of business.

\section{Number of Year's Beneficiaries Had Benefited from Sat Programmes}

The length of time within a programme by clients could have implications on their businesses. Adjei et al. (2009) [2] suggest that microfinance may be having increasingly negative impacts over time with recurring clients by impacting negatively on businesses. Implicitly, the longer number of years that individuals remain on the microfinance programmes does not necessarily 
result in continuous expansion and improvement in livelihoods and socio economic standards, thus rendering continual borrowing sceptical.

In this study, the number of years with SAT indicates the years that respondents had received loans from SAT. The analysis of years spent with SAT is shown in Table 4. The years were grouped into four and the results indicate that the majority (59.3\%) of the respondents had been with the trust from two to five years. About 10 percent of the respondents had been on the program more than ten years. The mean duration was four years.It could be inferred from the results that the objective and desire of halting continual borrowing by beneficiaries is being achieved by SAT since the majority reported that they had spent up to five years.

Table 4: Number of year's beneficiaries had received SAT services

\begin{tabular}{llc}
\hline Years with SAT & Frequency & Percent \\
\hline $2-5$ & 214 & 59.3 \\
$6-9$ & 111 & 30.7 \\
$10-13$ & 33 & 9.2 \\
$14+$ & 3 & 0.8 \\
\hline Total & 361 & 100.0 \\
\hline
\end{tabular}

Source: Field survey, 2012

Focus group discussions showed that the respondents borrowed with the initial aim of supporting their businesses by increasing their stocks and diversifying into other income generation activities. SAT management, in an interview, indicated that SAT aspires to provide services to assist their clients to mobilize their own business capital, implying that clients would grow into some level of capital sufficiency for their small businesses thereby reducing continual borrowing. Adjei (2010) [1], argues that focusing on increased income to ascertain the effects of microfinance on businesses does not necessarily enhance socio economic life and (Antoh Fredua, 2014) [5] suggests that the focus should be on the ability of the poor to sustain their businesses and wean themselves of persistent borrowing.

\section{Sources of Start-Up Funds of Beneficiaries}

Bortei-Doku and Aryeetey (1995) [9] have indicated that microfinance has the prospect of providing access to productive capital for the low income and poor and that the poor patronize microfinance programmes. However, considering the eligibility criteria for SAT loans which among others, requires the assessment of the borrower's existing business, the study set forth to find out how respondents acquired their start-up capital prior to SAT loans.

Table 5 indicates that majority (85.9\%) of the respondents used their personal savings as start-up capital. The rest (14.1\%) had started with family savings, SAT loan and other loans. It implies that individual funds used as initial capital play a significant role in starting own businesses. The results corroborate the general perception that initial capitals for businesses from banks are generally unattainable due to stringent collateral demands (Yunus, 2003) [43]. In the case of SAT, financial service officers reported that loans for start-up capital from SAT were mainly specialized loans arranged for small and medium scale businesses indicating that most clients did not start their businesses with SAT loans. The findings can be explained by the fact that to benefit from SAT services requires having an economic activity. 
Table 5: Sources of start-up capital of respondents

\begin{tabular}{lcc}
\hline Source of start-up & Frequency & Percent \\
\hline Personal savings & 310 & 85.9 \\
SAT loan & 22 & 6.1 \\
Family savings & 21 & 5.8 \\
Other M F loans & 4 & 1.1 \\
Others & 4 & 1.1 \\
Total & 361 & 100.0
\end{tabular}

Source: Field survey, 2012

Further analysis of start-up funds among the three SAT branches indicates variations within the sources. However, the personal and family savings and SAT loans were the most common sources as shown in Figure 2. The other sources of loan comprise credit from micro credit agencies and such as Susu and money lenders. These other categories, though insignificant were mostly (75\%) found in the Obuasi branch according to the analysis. The results corroborate the general perception that initial capitals for businesses from banks are generally unattainable due to stringent collateral demands (Yunus, 2003) [43].

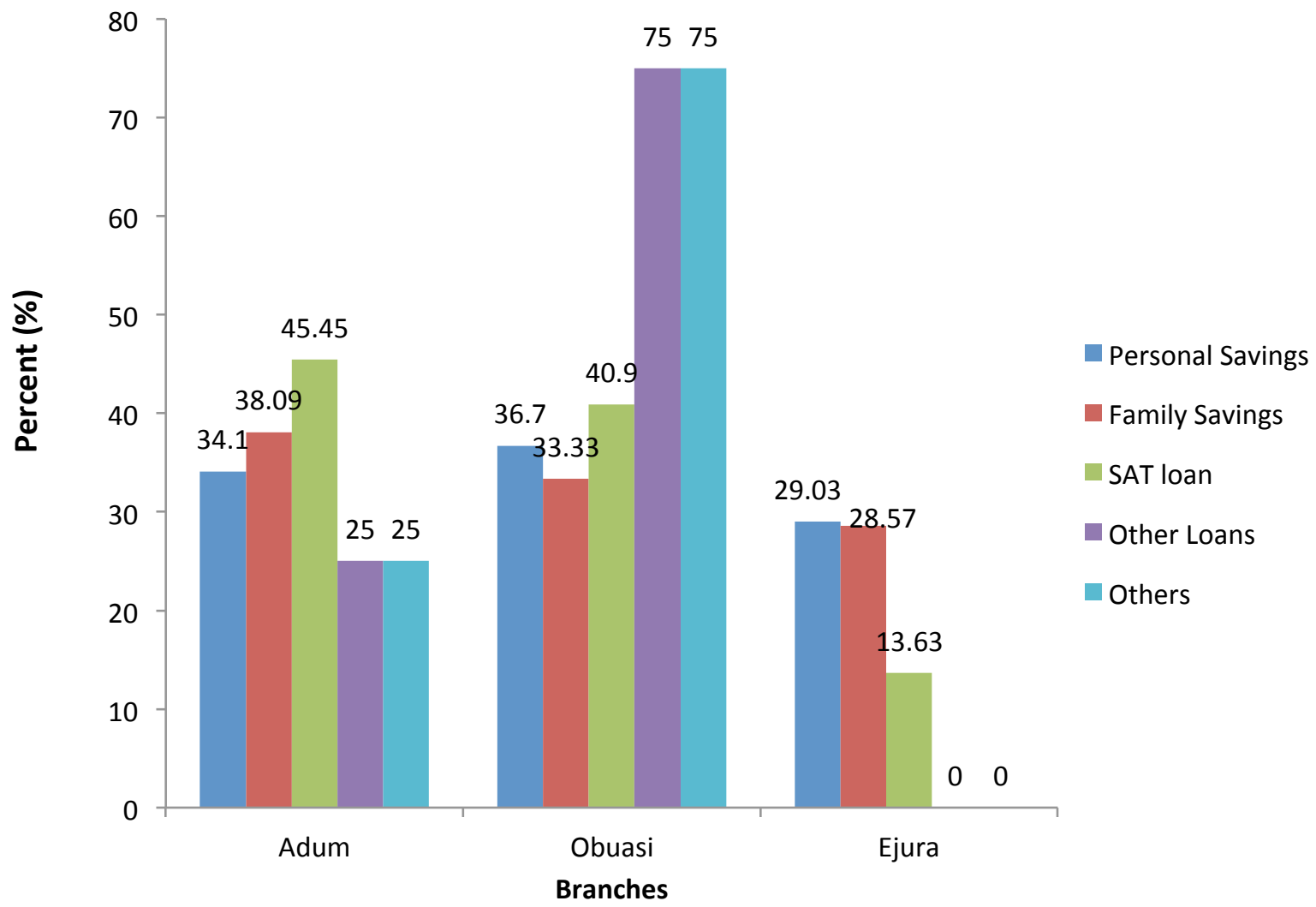

Figure 2: Sources of start-up capital of beneficiaries by SAT branches Source: Field survey, 2012

Business activities could be influenced by certain factors which could also affect the domains of change (Sebstad et al., 1995) [40]. The necessity in analyzing business is to present a picture of linkages between loans and peoples'businesses. Clients with different characteristics may go into different business activities tobuild viable businesses for themselves and their families (Afrane, 2002 [4]; Schrader, 1997 [39]). The type of businesses operated by respondents in this study is categorized into retail, agriculture/food, education/service and manufacturing. 
The analysis indicates that the majority (62\%) of the respondents were engaged in retail trade, 29 percent were into agriculture/food with the remaining respondents having their businesses in education/service and manufacturing as shown in Figure 3.

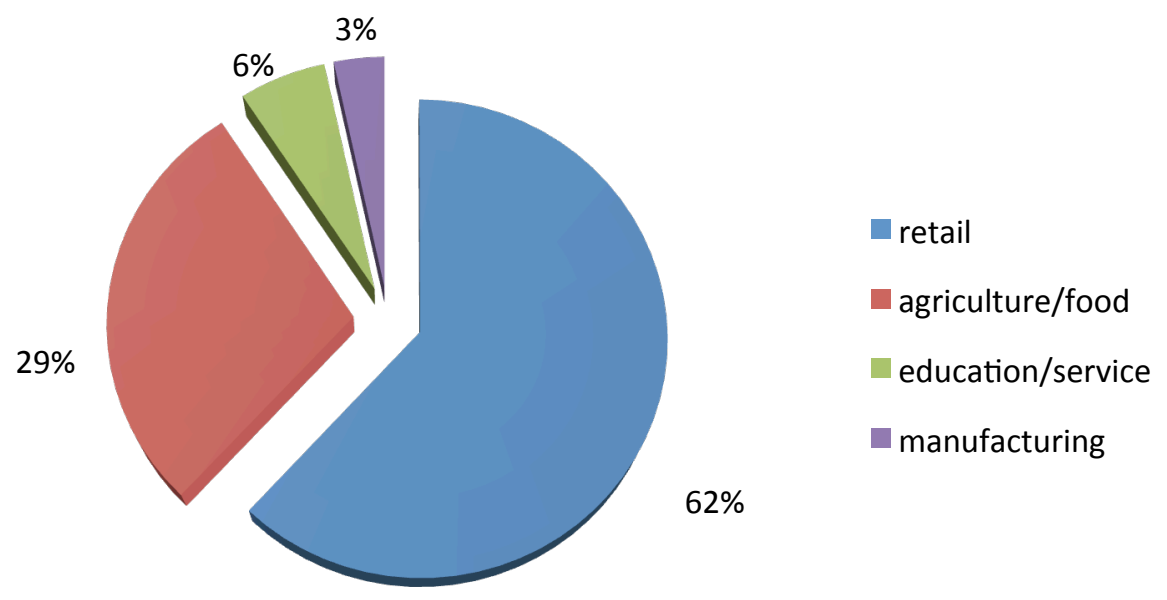

Figure 3: Business activities of respondents Source: Field survey, 2012

Further analysis was done on the type of businesses being undertaken by the respondents according to sex as shown in Table 6. About 62 percent of the females were in the retail business as compared to approximately 52 percent of males in the same sector. In Ghana, the retail sector is known to be dominated by women (GSS, 2013) [22]. This could be attributed to the circumstance that small initial capital and little or no technical acumen is needed to set up trade businesses thus making retail easily accessible or the best option for women who are among the poorest and non-literate(Carré, Holgate \& Tilly, 2005) [11]. Males, on the other hand, dominated the services and the manufacturing businesses which could be attributed to the technical expertise and financial requirements for such businesses (Broadbridge, 1997) [10]. The results in Table 6 seem to show that there is a relationship between sex and types of businesses of SAT beneficiaries and that the type of business type was influenced by sex.Further test for significant differences gave a chi-square statistics of 32.344 and a p-value of 0.000 indicating that the observed differences in type of businesses are not attributable to chance.

Table 6: Distribution of business types by sex

\begin{tabular}{lrrrrrr}
\hline Type of business & \multicolumn{2}{c}{ Female } & \multicolumn{3}{c}{ Male } & Total \\
Frequency $\%$ & Frequency & $\%$ & Frequency & $\%$ & & \\
& & & & & & \\
\hline Retail & 165 & 61.7 & 48 & 51.6 & 213 & 59.0 \\
Agriculture/food & 92 & 34.3 & 23 & 24.8 & 115 & 31.9 \\
Service(education) & 8 & 2.9 & 14 & 15.0 & 22 & 6.0 \\
Manufacturing & 3 & 1.1 & 8 & 8.6 & 11 & 3.1 \\
\hline Total & 268 & 100.0 & 93 & 100.0 & 361 & 100.0 \\
\hline
\end{tabular}

d.f $=3$; Chi-Square $=32.344 ;$ p-value $=0.000$

Source: Field survey, 2012

Based on the consideration or possibility that some beneficiaries would have other economic activities, respondents were asked whether they had other businesses that were not linked to 
the SAT program. From the survey, 33.5 percent of the beneficiaries indicated that they had other minor businesses whilst 66.5 percent indicated they had no other businesses. This implies that more than 60 percent of the respondents had incomes directly related to SAT services. The minor businesses were also dominated by retail, followed by agriculture/food and services such as education.

Microfinance beneficiaries meet some challenges which need to be identified to develop the necessary policies and actions to curb them. Beneficiaries provided varied responses in terms of challenges. It should be noted that although beneficiaries are confronted with multiple challenges they were asked to indicate the most severe. Analysis from the data reveals that the major challenges faced by the beneficiaries were seasonality of businesses (31.9\%), inadequate technical skills (23.3\%) and inadequate loans (22.4\%) as presented in Table 7. It was noted that the challenges were at both micro and macro levels and need a multifaceted approach to address individual, institutional and structural concerns. For instance, challenges such as high interest rates and inadequate financial resources were exogenous and beyond the control of beneficiaries.

Table 7: Challenges facing microfinance beneficiaries

\begin{tabular}{lcc}
\hline Challenge & Frequency & Percent \\
\hline Seasonality of business & 115 & 31.9 \\
Inadequate technical skills & 84 & 23.3 \\
Inadequate loans & 81 & 22.4 \\
No challenge & 35 & 9.7 \\
Inadequate inputs & 31 & 8.6 \\
Low profit & 7 & 1.9 \\
Robbery and theft & 4 & 1.1 \\
High interest rate & 4 & 1.1 \\
\hline Total & 361 & 100.0 \\
\hline
\end{tabular}

Source: Field survey, 2012

The various challenges cited by respondents is consistent with the claim that challenges faced by borrowers are multidimensional and could affect asset based development (Ellis \& Freeman, 2004) [16]. Interviews with the respondents indicated that loan officers and branch managers had regular interactions with the beneficiaries and their loan officers to learn of their challenges and discuss how to address them. In some cases, some debts of beneficiaries caused by circumstances beyond their control were written off or given different terms to settle their loans depending on the degree of loss. About 9.7 percent of the respondents reported that they did not experience any challenge in their businesses.

\section{CONCLUSION AND IMPLICATIONS}

The focus of the paper has been to ascertain the distinctive social and economic characteristics of microfinance beneficiaries in Ghana. The availability of reliable beneficiary characteristics helps to appreciate the socio economic development of low income people, who comprise majority of microfinance beneficiaries, to help devise relevant policies to enhance their status. The socio economic characteristics identified were age, sex, marital status, education level, number of children, sources of start-up capital and type of businesses.

The study result portrays that microfinance beneficiaries are dominated by females. Generally, the respondents comprised the economically active population and a larger population was married. Most beneficiaries had attained basic level education and similarly a bigger 
percentage had been on SAT programmes for less than ten years. Sources of start-up funds were mainly from individual beneficiaries and family savings which is not unusual since a major criterion for access to loans is evidence of an established business. Business types of beneficiaries were retail trade, agriculture/food, education/service and manufacturing and were predominated by retail trade which generally requires smaller start-up capitals. Disaggregated data indicated that females were dominantly in retail businesses. The services and manufacturing businesses were dominated by men who had the technical expertise and financial requirements for such businesses.The main challenges that the beneficiaries faced were seasonality of their business, inadequate technical skills and inadequate loans. The paper recommends the documentation of baseline characteristics of beneficiaries by microfinance institutions to facilitate empirical trend and transformation studies. It is also recommended that the training aspects of the microfinance program should be strengthened and SAT needs to re-visit the amounts of the loans that it provides.

The study institution has a national coverage, however due to resource constraints one region was studied which presents a limitation in relation to the size and composition of study respondents and could affect the representativeness and generality of the overview of study results. The study methodology particularly, the sampling techniques used aimed at achieving reasonable and reliable conclusions from the study.

\section{ACKNOWLEDGEMENTS}

Appreciation goes to the management and staff of Sinapi Aba Trust and clients especially those in Adum, Ejura Sekyedumasi and Obuasi branches in the Ashanti Region for their support in gathering data for the study.

\section{References}

1. Adjei, K. A. (2010). Microfinance and poverty reduction: The experience of Ghana. Accra: Bold Communications Limited.

2. Adjei, J. K., Arun, T., \& Hossain, F. (2009). The role of microfinance in asset - building and poverty reduction: The case of Sinapi Aba Trust of Ghana. Brooks World Poverty Institute Working Paper Series, 84. The University of Manchester, United Kingdom.

3. Afful, K. N., \& Annim, S. K. (2008). Finance, development and poverty nexus: A microfinance perspective in microfinance: A tool for achieving the millennium development goals, proceedings from the Third Microfinance Conference.

4. Afrane, S. (2002). Impact assessment of microfinance interventions in Ghana and South Africa. Journal of Microfinance, 4(1), 37-58.

5. Antoh, Ernestina Fredua (2014). Microfinance services of Sinapi Aba Trust and human capital development of beneficiaries in the Ashanti Region of Ghana. Doctor of Philosophy Dissertation. University of Cape Coast, Cape Coast.

6. Asiamah, J. P., \& Osei, V. (2007). Microfinance in Ghana: An overview.Accra: Research Department, Bank of Ghana.

7. Armendáriz de Aghion, B., \& Morduch, J. (2005). The economics of microfinance. Cambridge, MA: MIT Press.

8. Benhabib, J., \& Spiegai, M. M. (1994). The role of human capital in economic development: Evidence from aggregate cross-country data. Journal of Monetary Economics, 34(2), 143-174.

9. Bortei-Doku, E., \& Aryeetey, E. (1995). Mobilizing cash for business: Women in rotating Susu clubs in Ghana. In S. Ardener, \& S. Burman (Eds.), Money-go-rounds: The importance of rotating savings and credit associations for women (pp.77-94). Oxford: Berg.

10. Broadbridge, A. (1997). Why earnings are different for men and women in retailing. Service Industries Journal, 17(2), $221-236$. 
11. Carré, F., Holgate, B., \& Tilly, C. (2005). What's happening to retail jobs? Wages, gender and corporate strategy. Presented at the International Association for Feminist Economics and the Labor and Employment Relations Association. Boston, M.A.

12. Cheston, S., \& Kuhn, L. (2002). Empowering women through microfinance, pathways out of poverty: Innovations in microfinance for the poorest families. Bloomfield: Kumarian Press.

13. Dennis, C., \&Peprah, E. (1995). Coping with transition through organisation: Techiman Market. Gender and Development, 3(3), 43-48.

14. Duryea, S., \& Pagés, C. (2002). Human capital policies: What they can and cannot do for productivity and poverty reduction in Latin America. Working Paper No. 468. Washington, D.C.: Inter-American Development Bank.

15. Ekpe, I., Mat, N. B., \& Razak, R. C. (2010). The effect of microfinance factors on women entrepreneurs' performance in Nigeria: A conceptual framework. International Journal of Business and Social Science,1(2), 255-263.

16. Ellis, F., \& Freeman, H. (2004). Rural livelihoods and poverty reduction strategies in four African countries. Journal of Development Studies, 40(4), 1-30.

17. Ghalib, A. K. (2009). Measuring the impact of microfinance intervention: a conceptual framework of social impact assessment. IARC working papers series no. 24.

18. Ghana Statistical Service (GSS). (2005). Ghana population data analysis report. Accra: GSS.

19. Ghana Statistical Service. (2008). Ghana Living Standards Survey Report of the Fifth Round (GLSS 5). Accra: GSS

20. Ghana Statistical Service. (2011). Population and housing census: Provisional results. Accra: GSS.

21. Ghana Statistical Service. (2012). 2010 Population and housing census: Summary report of final results. Accra: GSS.

22. Ghana Statistical Service (2013). 2010 Population and housing census: National analytical report. Accra: GSS.

23. Gibb, S. (2008). Microfinance's impact on education, poverty and empowerment: A case study from the Bolivian Altiplano. Development Research Working paper series No. 04/2008. Institute for Advanced Development Studies. [Author from the University of Aalborg, Denmark.

24. Hazarika, G \& Sudipta, S (2007. Household access to microcredit and child work in rural Malawi. World Development, 36 (5), 843-859.

25. Hossain, M. (1988). Credit for alleviation of rural poverty: The Grameen Bank in Bangladesh. IFPRI Research report, 65.Washington, D. C.:IFPRI.

26. Ikeanyibe, M. O. (2008). Human resource management for sustainable microfinance institutions in Nigeria. Global Journal of Social Sciences, 8(1), 119-134.

27. Khandker, R. S. (2005). Microfinance and poverty: Evidence using panel data from Bangladesh. The World Bank Economic Review, 19 (2), 263-286.

28. Khavul, S. (2010). Microfinance: Creating opportunities for the poor? Academy of Management, 24, 3 5872.

29. Kotir, J. H., \& Obeng-Odoom, F. (2009). Microfinance and rural household development: A Ghanaian perspective. Journal of Developing Societies, 25(1), 85-105.

30. Krejcie, R.V., \& Morgan, D. W. (1970). Determining sample size for research activities. In Sarantakos, S. (1998). Social research (pp. 163). Hong Kong: MacMillan Press.

31. Kumasi Metropolitan Area (KMA) (2005). Development Plan, 2002-2004. KMA, Kumasi.

32. Mahjabeen, R. (2008). Micro financing in Bangladesh: Impact on households, consumption and welfare. Journal of Policy Modelling, 30, 1083-1092. 
33. Mahjabeen, R. (2008). Micro financing in Bangladesh: Impact on households, consumption and welfare. Journal of Policy Modelling, 30, 1083-1092.

34. Matin, I., \& Begum, A. S. (2002). Asset-ing the extreme poor: Experiences and Lessons from a BRAC Project. Discussion Paper, Research and Evaluation Division, Bangladesh Rural Development Committee, Dhaka, Bangladesh.

35. Nader, Y. F. (2008). Microcredit and socio-economic well-being of women and their families in Cairo. Journal of Socio-economics, 37(2), $644-656$.

36. Pallant, J. (2005). SPSS survival manual, a step by step guide to data analysis using SPSS Version 12. Chicago, Illinois. Allen \& Unwin.

37. Rankin, K. N. (2002). Social capital, microfinance, and the politics of development. Feminist Economics, $8(1), 1-24$.

38. Robinson, M. S. (2001). The microfinance revolution: Sustainable finance for the poor. Washington D.C: The World Bank: Open Society Institute.

39. Sarantakos, S. (2005). Social research. London: Palgrave Macmillan.

40. Schrader, H. (1997). Changing financial landscapes in India and Indonesia: Sociological aspects of monetization and market integration. St. Martin's. New York: LIT, Muenster.

41. Sebstad, J., Neill, C., Barnes, C., \& Chen, G. (1995). Assessing the Impacts of Microenterprise Interventions: A Framework for Analysis. Washington DC: USAID.

42. Shane, S. (2003). A general theory of entrepreneurship: The individual opportunity nexus. UK: Edward Elgar.

43. Sinapi Aba Trust (SAT) (2008). Operational Report.

44. Yunus, M. (2003). Expanding microcredit outreach to reach the millennium development goal: Some issues for attention. Retrieved on February 13, 2009://www.microfinancegateway.org/files/3642_Yunus3.doc.

45. Zohir, S., \& Matin, I. (2004). Wider impact of microfinance institutions: Issues and concepts. Journal of International Development, 16, 301-330. 